CHARLES DICKENS 
This page intentionally left blank 


\title{
Charles Dickens
}

\author{
MICHAEL SLATER
}


Copyright (c) 2009 by Michael Slater

All rights reserved. This book may not be reproduced in whole or in part, in any form (beyond that copying permitted by Sections 107 and 108 of the U.S. Copyright Law and except by reviewers for the public press), without written permission from the publishers.

For information about this and other Yale University Press publications please contact:

U.S. Office: sales.press@yale.edu www.yalebooks.com

Europe Office: sales@yaleup.co.ukwww.yalebooks.co.uk

Set in Minion by IDSUK (DataConnection) Ltd.

Printed in the United States of America.

Library of Congress Cataloging-in-Publication Data

Slater, Michael.

Charles Dickens : a life defined by writing / Michael Slater.

p. $\mathrm{cm}$.

Includes bibliographical references and index.

ISBN 978-0-300-11207-8

1. Dickens, Charles, 1812-1870. 2. Authors, English-19th

century-Biography. I.Title.

PR4581.S6155 2009

823 '.8-dc22

[B]

ISBN 978-0-300-11207-8

A catalogue record for this book is available from the British Library

10987654321 
This book is dedicated to the memory of Kathleen Tillotson 1906-2001

mentor and friend 
This page intentionally left blank 